\title{
Synthesis of antibacterial 1,3-diyne-linked peptoids from an Ugi-4CR/Glaser coupling approach
}

\author{
Martin C. N. Brauer, Ricardo A. W. Neves Filho, Bernhard Westermann, Ramona Heinke \\ and Ludger A. Wessjohann*§
}

\author{
Full Research Paper \\ Address: \\ Department of Bioorganic Chemistry, Leibniz Institute of Plant \\ Biochemistry, Weinberg 3, D-06120 Halle/Saale, Germany \\ Email: \\ Ludger A. Wessjohann* - wessjohann@ipb-halle.de \\ * Corresponding author \\ § Fax: +49 3455582 1309; Tel: +49 34555821301 \\ Keywords: \\ antibacterial; combinatorial; diynes; homodimerization; \\ multicomponent reactions; peptoids; Ugi reaction
}

\author{
Beilstein J. Org. Chem. 2015, 11, 25-30. \\ doi:10.3762/bjoc. 11.4
}

Received: 29 October 2014

Accepted: 23 December 2014

Published: 07 January 2015

This article is part of the Thematic Series "Multicomponent reactions II".

Guest Editor: T. J. J. Müller

(c) 2015 Brauer et al; licensee Beilstein-Institut. License and terms: see end of document.

\begin{abstract}
A library of ten 1,3-diyne-linked peptoids has been synthesized through an Ugi four-component reaction (U-4CR) followed by a copper-catalysed alkyne homocoupling (Glaser reaction). The short and chemoselective reaction sequence allows generating diverse (pseudo) dimeric peptoids. A combinatorial version allows the one-pot preparation of, e.g., six-compound-libraries of homo- and heterodimers verified by ESI-MS and HPLC. In a preliminary evaluation, some compounds display moderate activity against the Gram-positive bacterium Bacillus subtilis.
\end{abstract}

\section{Introduction}

A re-occurring principle of nature to mediate or increase biological activity is dimerization [1]. Many protein receptors dimerize upon activation and recruit their active form by this transformation. This process is mainly initiated by dimeric natural products or symmetric bivalent ligands, which can be of peptidic origin [2,3]. As an example, Harran and co-workers synthesized a low-molecular weight $C_{2}$-symmetric 1,3-diynelinked peptide 1 which was able to mimic the function of Smac (second mitochondria-derived activator of caspase) protein by triggering caspase 8 activation as well as apoptosis at concentrations as low as $100 \mathrm{pM}$. The higher activity of $\mathbf{1}$ in comparison to $\mathbf{2}$ (Figure 1 ) is possibly related to the ability of $\mathbf{1}$ to interact simultaneously with adjacent baculovirus inhibitory repeat (Bir) domains in the human $\mathrm{X}$ chromosome that encodes IAP (inhibitor of apoptosis) [4]. In another study Chen and co-workers found a GLP-1R antagonist only because of an unexpected dimerization [5]; and a dimer of $S$-adenosylmethionine is up to 13 -fold more active than the monomer for promoting the binding of Escherichia coli methionine repressor to its operator DNA [6].

Peptoids are compounds which are able to mimic peptide structures [7-9]. In addition to the mimetic function, these compounds also possess an enhanced resistance to proteolytic 


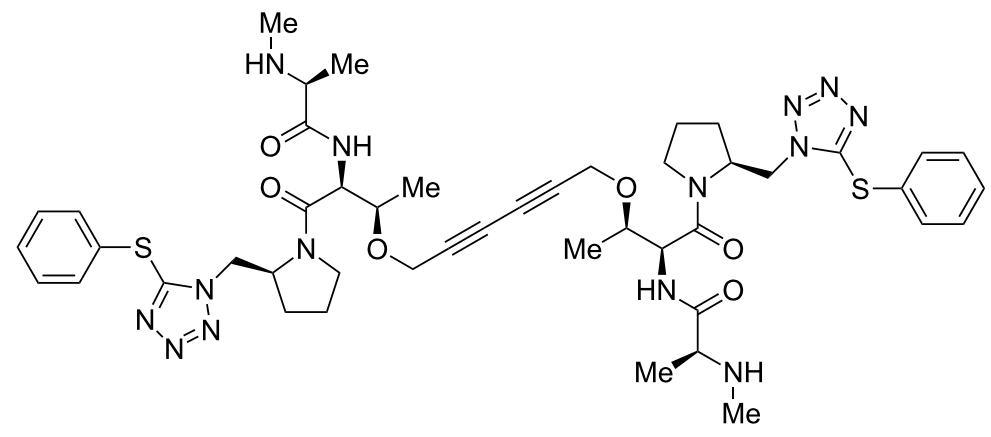

1

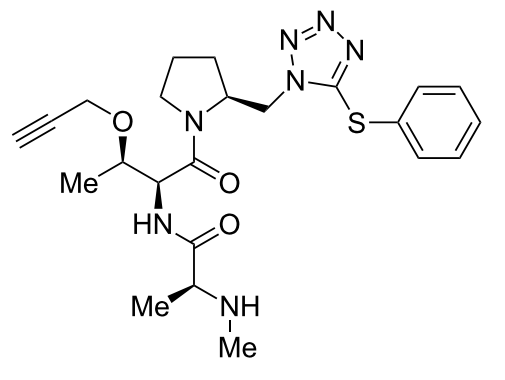

2

Figure 1: Apoptosis inducer $C_{2}$-symmetric 1,3-diyne-linked peptide 1 and its inactive monomer 2.

enzymes. The fastest method for synthesizing peptoids is the Ugi four-component reaction (U-4CR) [10-12]. In combination with other protocols, this reaction has been used in the synthesis of bioactive peptides and pseudopeptides, e.g., tubulysin mimetics [13], julocrotine derivatives [14], architecturally complex peptoid macrocycles $[15,16]$, building blocks for diversityoriented synthesis [17], and heterocyclic compounds [18]. Complex structures as well as simple Ugi products exhibit promising biological profiles, e.g., cytotoxicity $[13,19,20]$, fungicidal $[21,22]$ and antibacterial properties [23-26], or inhibition of histone deacetylases [27]. The Ugi post-modification strategy has also been employed in the synthesis of heterocyclic and natural product inspired compounds [28-32]. Although several protocols of U-4CR followed by transition metal-catalysed reactions have been published so far [33], to the best of our knowledge, there are no reports about U-4CR/Glaser-type (homo) coupling combinations.

In view of an increasing interest to synthesize dimerized peptidomimetics with pharmacological properties through a step-efficient protocol that allows rapid access to highly diverse dimer libraries, we set out to develop a strategy based on an U-4CR/Glaser-type homocoupling sequence [34]. In comparison to popular cross linking reactions like, e.g., click reactions or amide bonds, the Glaser coupling allows the use of truly identical monomers. This decreases the number of steps for appropriate starting materials, and allows access to true homodimers in sensu strictu.

\section{Results and Discussion}

To achieve the synthesis of monomers eligible for dimerizations by Glaser coupling, equimolar amounts of propargylamine (3), aldehyde 4, carboxylic acid 5, and isocyanides 6 were reacted in methanol at room temperature over $24 \mathrm{~h}$ following well established Ugi protocols [12]. After flash column chromatography $N$-propargyl peptoids $7 \mathbf{a}-\mathbf{j}$ were obtained in good yields. The next step was the copper-catalysed homocoupling (Glaser reaction) of the terminal alkyne functions. Albeit several protocols are reported for this reaction, the $\mathrm{CuCl}$-catalyzed method recently described by Jia and co-workers was utilised to access the $C_{2}$-symmetric 1,3-diynes because it does not require expensive catalysts, ligands, or additives (Table 1) [34]. The coupling reaction was clean without notable side product formation as confirmed by TLC analysis, and the desired peptoid dimers $\mathbf{8 a}-\mathbf{j}$ could be obtained in high to quantitative yields. Aromatic as well as aliphatic carboxylic acids and aldehydes have been successfully employed in both multicomponent and coupling reactions. When performing the reaction with methyl isocyanoacetate (Table 1 , entry 2 ) the desired products could be obtained in good yields with the ester group remaining untouched. It is important to note that different protecting groups can be used: Boc-, PhAc- and Cbz-protected peptoid derivatives (Table 1, entries 8-10) reacted to the corresponding dimers $\mathbf{7} \mathbf{h}-\mathbf{j}$ without complications. The structure of the compounds $\mathbf{7} \mathbf{a}-\mathbf{j}$, as well as $\mathbf{8} \mathbf{a}-\mathbf{j}$, have been confirmed by ${ }^{1} \mathrm{H},{ }^{13} \mathrm{C}$ NMR spectra, and HRMS. In addition, HPLC analyses revealed that an adjacent stereocenter (Table 1 , entry $8, \mathbf{7 h} / \mathbf{8 h}$ ) does not racemize under the reaction conditions of both the MCR and the Glaser coupling.

Due to the high selectivity and high conversions found in the Glaser coupling step, our attention turned toward the development of a combinatorial version of the copper-catalysed homodimerization. In this strategy two or more alkyne peptoids should couple simultaneously in the same reaction vessel in order to generate small libraries of dimers. In contrast to parallel synthesis, the combinatorial approach easily generates non-symmetric dimers $\mathbf{9 , 1 0}$ and $\mathbf{1 1}$. Thus, the peptoids $\mathbf{7 f}, \mathbf{7 h}$ and $7 \mathbf{j}$ were pooled to a Glaser reaction as depicted in Scheme 1. 
Table 1: Synthesis of compounds $7 \mathbf{a}-\mathbf{j}$ and $\mathbf{8 a}-\mathbf{j}$.

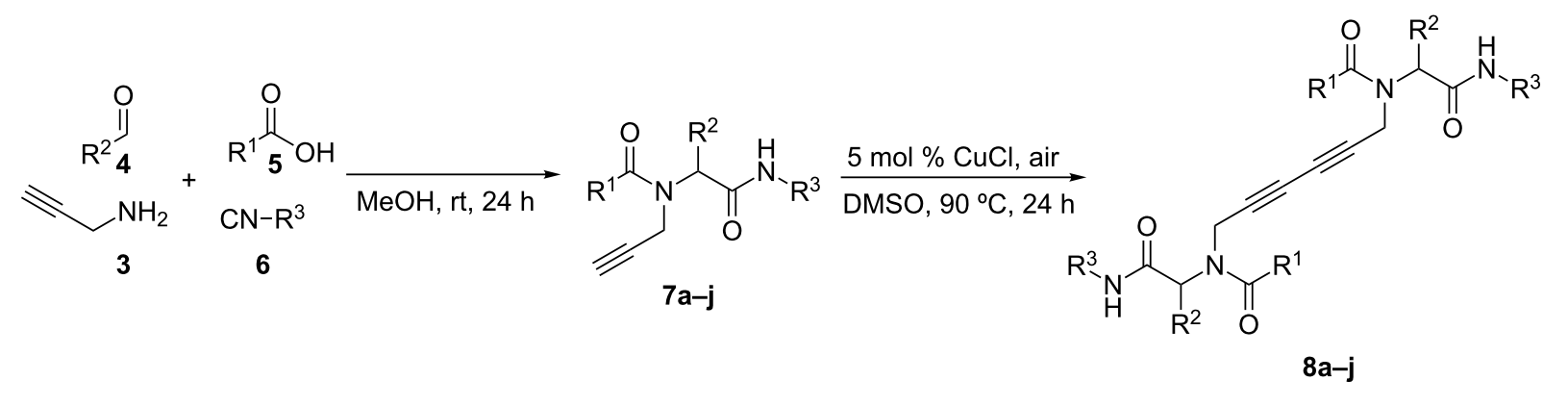

\begin{tabular}{|c|c|c|c|c|c|}
\hline Entry & $\mathrm{R}^{1}$ & $\mathrm{R}^{2}$ & $\mathrm{R}^{3}$ & $\begin{array}{c}\text { Monomer } 7 \\
\text { yield (\%) }\end{array}$ & $\begin{array}{r}\text { Dimer } 8 \\
\text { yield }(\%)\end{array}$ \\
\hline 1 & $\mathrm{CH}_{3}$ & & & $\begin{array}{l}7 a \\
97\end{array}$ & $\begin{array}{l}8 \mathrm{a} \\
88\end{array}$ \\
\hline 2 & $\mathrm{CH}_{3}$ & & & $\begin{array}{l}7 b \\
95\end{array}$ & $\begin{array}{l}8 \mathbf{b} \\
80\end{array}$ \\
\hline 3 & $\mathrm{CH}_{3}$ & & & $\begin{array}{l}\text { 7c } \\
99\end{array}$ & $\begin{array}{l}8 c \\
99\end{array}$ \\
\hline 4 & $\mathrm{Ph}$ & & & $\begin{array}{l}7 d \\
70\end{array}$ & $\begin{array}{l}\text { 8d } \\
91\end{array}$ \\
\hline 5 & $t_{7}$ & & & $\begin{array}{l}7 e \\
91\end{array}$ & $\begin{array}{l}8 \mathbf{e} \\
99\end{array}$ \\
\hline 6 & $n^{n} \mathrm{C}_{3} \mathrm{H}_{7}$ & $\mathrm{H}$ & & $\begin{array}{l}7 f \\
70\end{array}$ & $\begin{array}{l}8 f \\
99\end{array}$ \\
\hline 7 & & & & $\begin{array}{l}7 \mathrm{~g} \\
98\end{array}$ & $\begin{array}{l}8 \mathrm{~g} \\
97\end{array}$ \\
\hline 8 & & $\mathrm{H}$ & & $\begin{array}{l}7 \mathrm{~h} \\
82\end{array}$ & $\begin{array}{l}8 \mathrm{~h} \\
99\end{array}$ \\
\hline 9 & & & & $\begin{array}{l}7 i \\
82\end{array}$ & $\begin{array}{l}8 \mathrm{i} \\
96\end{array}$ \\
\hline 10 & & $\mathrm{H}$ & $\xi<$ & $\begin{array}{l}7 \mathrm{j} \\
80\end{array}$ & $\begin{array}{l}8 \mathbf{j} \\
99\end{array}$ \\
\hline
\end{tabular}

The ESI-MS spectrum of the crude library confirmed the presence of all expected Glaser-coupled products $8 \mathbf{8}, \mathbf{8 h}, \mathbf{8 j}, \mathbf{9}$, 10 and 11. The HPLC-MS analysis of the composition resulted in six peaks with different retention times and intensities identified via MS as the six desired components of the library. Figure 2 illustrates the expanded region of the ESI-MS spectrum (positive mode) and the HPLC chromatogram with the respective assignments of the obtained peaks. The analysis of the obtained spectra revealed that the non-symmetric dimers $\mathbf{9}$, $\mathbf{1 0}$ and $\mathbf{1 1}$ are formed preferentially. The abundance differences observed are mostly lower than 2-fold, in one case up to ca. 4-fold. This is still acceptable for our initial bioactivity assays, as most screening setups cover several orders of magnitude of concentration anyhow. Therefore no further attempt to optimize for an equal product distribution was deemed necessary.

To gain insight into the antibiotic potential of the products, single compound dimers $\mathbf{8 a}-\mathbf{j}$ were subjected to a preliminary evaluation against Bacillus subtilis (Figure 3) [35,36]. The 


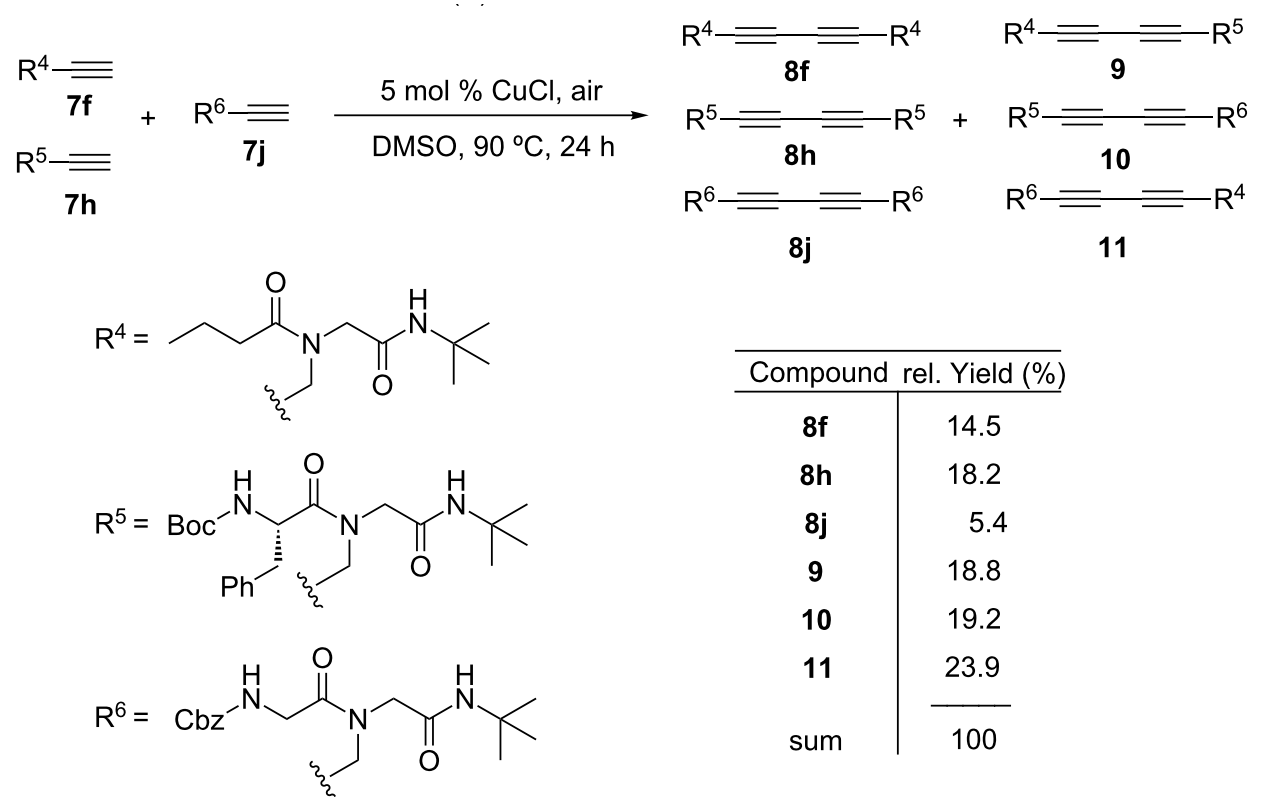

Scheme 1: Combinatorial Glaser coupling involving acetylenes $7 \mathbf{f}, 7 \mathbf{j}$ and $7 \mathbf{h}$.
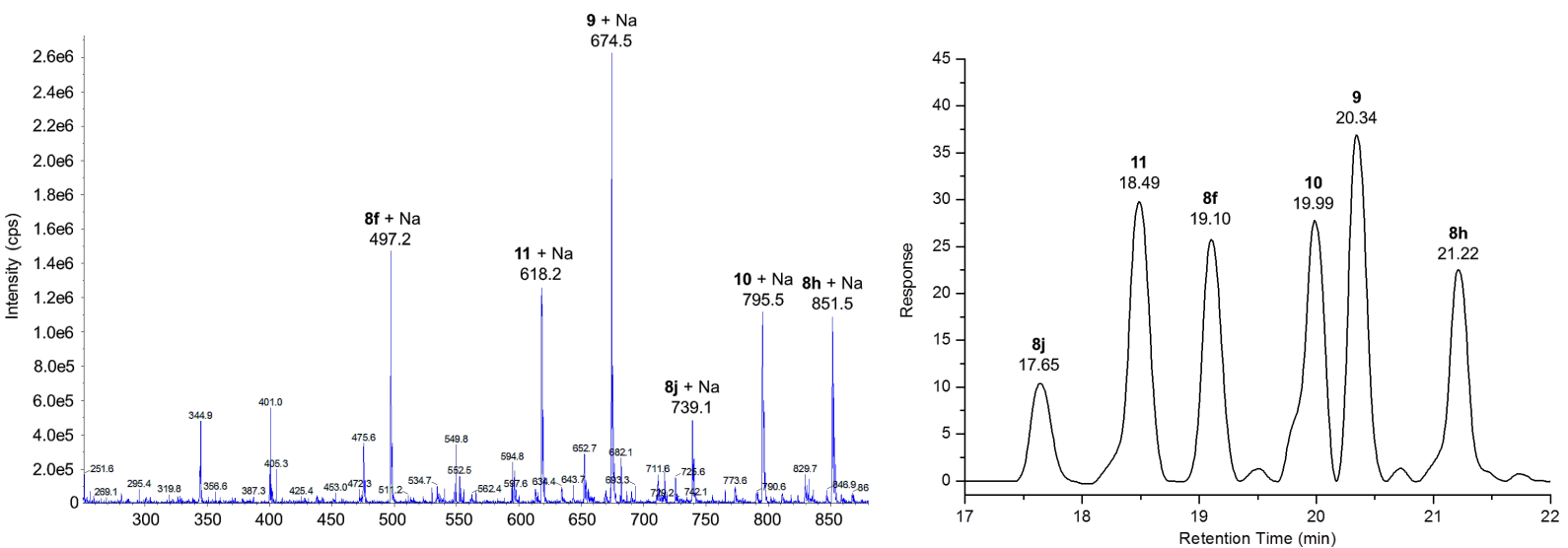

Figure 2: Expanded region of the ESI-MS spectrum (positive mode) and the HPLC chromatogram of the crude mixed library of 1,3-diyne peptoids (8f $\mathbf{8 h}, \mathbf{8 j}, \mathbf{9}, 10$ and $\mathbf{1 1}$ ) produced by a combinatorial Glaser coupling of three different monomers (see Scheme 1).

active compounds inhibited bacterial growth in a range from $29 \%$ to $44 \%$ at $1 \mu \mathrm{M}$ concentration, while erythromycin as the standard led to a growth inhibition of $71 \%$ under the same assay conditions. The most active compounds were $\mathbf{8 b}, \mathbf{8 d}$ and $\mathbf{8 h}$ which displayed inhibition rates (\%) of $44.0 \pm 26.7,44.0 \pm 21.8$ and $43.9 \pm 23.0$. Interestingly, compounds $8 \mathbf{c}$ and $\mathbf{8 f}$ showed almost no effect on bacterial growth, i.e., $1.3 \pm 5.1 \%$ and $2.3 \pm 13.5 \%$, respectively, i.e., the diyne core fulfils its function as linker and spacer without itself negatively (or positively) influencing the specific activity of the active ligand moieties.

\section{Conclusion}

In summary, a reliable sequential U-4CR/Glaser coupling approach towards the synthesis of 1,3-diyne-linked peptoids was developed. The strategy resulted in a library consisting of ten homodimers in good yields. The post-MCR copper-catalysed homocoupling reaction has also been performed in a combinatorial fashion combining three monomers. This procedure resulted in a mixed library containing six 1,3-diyne-linked symmetric and non-symmetric peptoids as confirmed by ESI-MS and HPLC experiments. Some of the synthesized compounds 8a-j 


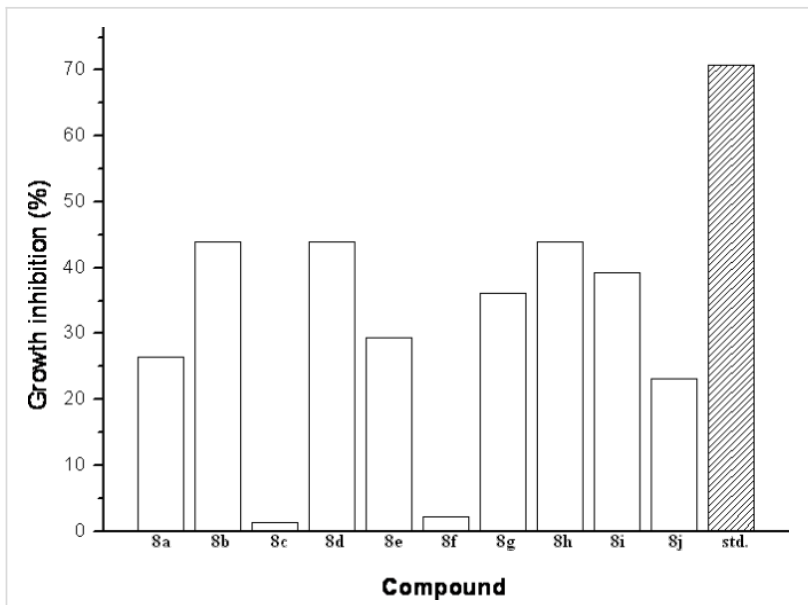

Figure 3: Growth inhibition of Bacillus subtilis by compounds $\mathbf{8 a - j}$ at $1 \mu \mathrm{M}(15 \mathrm{~h})$, and standard erythromycin at $1 \mu \mathrm{M}(15 \mathrm{~h})$.

displayed growth inhibitory activity against Bacillus subtilis in a preliminary assay.

\section{Supporting Information}

\section{Supporting Information File 1}

Complete experimental procedures, characterization and figures of ${ }^{1} \mathrm{H}$ and ${ }^{13} \mathrm{C}$ NMR spectra.

[http://www.beilstein-journals.org/bjoc/content/ supplementary/1860-5397-11-4-S1.pdf]

\section{Acknowledgements}

The authors acknowledge support from the State of SaxonyAnhalt (MK-LSA, Projekt "Lipopeptide"). We thank Dr. Jürgen Schmidt and Ms. Anja Ehrlich for HRMS and HPLC support, repectively. M.C.N.B and R.A.W.N.F. thank the Brazilian National Research Council (CNPq) for Ph.D. fellowships; R.H. gratefully acknowledges support by the Studienstiftung des Deutschen Volkes.

\section{References}

1. Marianayagan, N. J.; Sunde, M.; Mathews, J. M. Trends Biochem. Sci. 2004, 29, 618-625. doi:10.1016/j.tibs.2004.09.006

2. Hadden, M. K.; Blagg, B. S. J. Anti-Cancer Agents Med. Chem. 2008, 8, 807-816. doi:10.2174/187152008785914743

3. Lian, G.; Yu, B. Chem. Biodiversity 2010, 7, 2660-2691. doi:10.1002/cbdv.201000038

4. Li, L.; Thomas, R. M.; Suzuki, H.; De Brabander, J. K.; Wang, X.; Harran, P. G. Science 2004, 305, 1471-1474. doi:10.1126/science.1098231

5. Chen, D.; Liao, J.; Li, N.; Zhou, C.; Liu, Q.; Wang, G.; Zhang, R.; Zhang, S.; Lin, L.; Chen, K.; Xie, X.; Nan, F.; Young, A. A.; Wang, M.-W. Proc. Natl. Acad. Sci. U. S. A. 2007, 104, 943-948. doi:10.1073/pnas.0610173104
6. Joce, C.; White, R.; Stockley, P. G.; Warriner, S.; Turnbull, W. B.; Nelson, A. Bioorg. Med. Chem. Lett. 2012, 22, 278-284. doi:10.1016/j.bmcl.2011.11.017

7. Seo, J.; Lee, B.-C.; Zuckermann, R. N. Comprehensive Biomaterials; Elsevier: Amsterdam, 2011; Vol. 2, pp 53-76. doi:10.1016/B978-0-08-055294-1.00256-7

8. Vagner, J.; Qu, H.; Hruby, V. J. Curr. Opin. Chem. Biol. 2008, 12, 292-296. doi:10.1016/j.cbpa.2008.03.009 And references cited therein

9. Zuckermann, R. N.; Kerr, J. M.; Kent, S. B. H.; Moos, W. H. J. Am. Chem. Soc. 1992, 114, 10646-10647. doi:10.1021/ja00052a076

10. Zhu, J.; Bienaymé, H., Eds. Multicomponent Reactions; Wiley-VCH: Weinheim, Germany, 2005. doi:10.1002/3527605118

11. Vercillo, O. E.; Andrade, C. K. L.; Wessjohann, L. A. Org. Lett. 2008, 10, 205-208. doi:10.1021/ol702521g

12. Wessjohann, L. A.; Kaluderovic, G.; Neves Filho, R. A. W.; Morejon, M. C.; Lemanski, G.; Ziegler, T. Multicomponent Reactions 1 : Further Components Carboxylic Acids and Amine (Ugi Reaction). In Science of Synthesis; Müller, T. J. J., Ed.; Thieme: New York, 2013; pp 415-497.

13. Pando, O.; Stark, S.; Denkert, A.; Porzel, A.; Preusentanz, R.; Wessjohann, L. A. J. Am. Chem. Soc. 2011, 133, 7692-7695. doi:10.1021/ja2022027

14. Neves Filho, R. A. W.; Westermann, B.; Wessjohann, L. A. Beilstein J. Org. Chem. 2011, 7, 1504-1507. doi:10.3762/bjoc.7.175

15. Rivera, D. G.; Wessjohann, L. A. Molecules 2007, 12, 1890-1899. doi:10.3390/12081890

16. Rivera, D. G.; Wessjohann, L. A. J. Am. Chem. Soc. 2009, 131, 3721-3732. doi:10.1021/ja809005k

17. Neves Filho, R. A. W.; Stark, S.; Morejon, M. C.; Westermann, B.; Wessjohann, L. A. Tetrahedron Lett. 2012, 53, 5360-5363. doi:10.1016/j.tetlet.2012.07.064

18. Akritopoulou-Zanze, I.; Djuric, S. W. Heterocycles 2007, 73, 125-147. doi:10.3987/REV-07-SR(U)3

19. Yamada, R.; Cao, X.; Butkevich, A. N.; Millard, M.; Odde, S.; Mordwinkin, N.; Gundla, R.; Zandi, E.; Louie, S. G.; Petasis, N. A.; Neamati, N. J. Med. Chem. 2011, 54, 2902-2914. doi:10.1021/jm101655d

20. Olsen, C. A.; Ziegler, H. L.; Nielsen, H. M.; Frimodt-Møller, N.; Jaroszewski, J. W.; Franzyk, H. ChemBioChem 2010, 11, 1356-1360. doi:10.1002/cbic.201000232

21. Galetti, M. D.; Cirigliano, A. M.; Cabrera, G. M.; Ramírez, J. A. Mol. Diversity 2012, 16, 113-119. doi:10.1007/s11030-011-9334-1

22. Lamberth, C.; Jeanguenat, A.; Cederbaum, F.; De Mesmaeker, A.; Zeller, M.; Kempf, H.-J.; Zeun, R. Bioorg. Med. Chem. 2008, 16, 1531-1545. doi:10.1016/j.bmc.2007.10.019

23. Socha, A. M.; Tan, N. Y.; LaPlante, K. L.; Sello, J. K. Bioorg. Med. Chem. 2010, 18, 7193-7202. doi:10.1016/j.bmc.2010.08.032

24. Neves Filho, R. A. W.; Stark, S.; Westermann, B.; Wessjohann, L. A. Beilstein J. Org. Chem. 2012, 8, 2085-2090. doi:10.3762/bjoc.8.234

25. Kodadek, T. Chem. Biol. 2013, 20, 1202-1203. doi:10.1016/j.chembiol.2013.10.006

26. Hu, Y.; Amin, M. N.; Padhee, S.; Wang, R. E.; Qiao, Q.; Bai, G.; Li, Y.; Mathew, A.; Cao, C.; Cai, J. ACS Med. Chem. Lett. 2012, 3, 683-686. doi:10.1021/ml3001215

27. Grolla, A. A.; Podestà, V.; Chini, M. G.; Di Micco, S.; Vallario, A.; Genazzani, A. A.; Canonico, P. L.; Bifulco, G.; Tron, G. C.; Sorba, G.; Pirali, T. J. Med. Chem. 2009, 52, 2776-2785. doi:10.1021/jm801529c 
28. Keating, T. A.; Armstrong, R. W. J. Am. Chem. Soc. 1996, 118, 2574-2583. doi:10.1021/ja953868b

29. Hulme, C.; Gore, V. Curr. Med. Chem. 2003, 10, 51-80. doi:10.2174/0929867033368600

30. Hulme, C.; Morrissette, M. M.; Volz, F. A.; Burns, C. J. Tetrahedron Lett. 1998, 39, 1113-1116. doi:10.1016/S0040-4039(97)10795-X

31. Wessjohann, L. A.; Rhoden, C. R. B.; Rivera, D. G.; Vercillo, O. E. Top. Heterocycl. Chem. 2010, 23, 199-226. doi:10.1007/7081_2009_25

32. Wessjohann, L. A.; Ruijter, E. Top. Curr. Chem. 2005, 243, 137-184. doi:10.1007/b96883

33. Koopmanschap, G.; Ruijter, E.; Orru, R. V. A. Beilstein J. Org. Chem. 2014, 10, 544-598. doi:10.3762/bjoc. 10.50

34. Yin, K.; Li, C.; Li, J.; Jia, X. Green Chem. 2011, 13, 591-593. doi:10.1039/c0gc00413h

35. Heinke, R.; Franke, K.; Porzel, A.; Wessjohann, L. A.; Ali, N. A. A.; Schmidt, J. Phytochemistry 2011, 72, 929-934. doi:10.1016/j.phytochem.2011.03.008

36. Michels, K.; Heinke, R.; Kuipers, O. P.; Arnold, N.; Wessjohann, L. A J. Antibiot. submitted.

\section{License and Terms}

This is an Open Access article under the terms of the Creative Commons Attribution License

(http://creativecommons.org/licenses/by/2.0), which permits unrestricted use, distribution, and reproduction in any medium, provided the original work is properly cited.

The license is subject to the Beilstein Journal of Organic Chemistry terms and conditions:

(http://www.beilstein-journals.org/bjoc)

The definitive version of this article is the electronic one which can be found at: doi:10.3762/bjoc. 11.4 